As Count Ahlefeldt tells us, hunting is almost his profession and this is evident in his account of the pursuit of the animals he collected. At the same time one can share the excitement and fascination he obviously felt when quietly watching wild creatures at home. It comes as somewhat of a shock therefore to see photographs with captions such as "Measuring Museum's Rhino-cow, where she rolled down to rest". Surely few people want to see pictures of fine animals lying dead, even if they were killed in a scientific cause. The photographs are not a strong feature of this book.

The book is translated from the Danish, and this may explain the incorrect statement that rinderpest is carried by certain kinds of tsetse fly. A map shows the several safari routes, based on Nairobi, and at the end there is an appendix giving notes on the collections made. The expedition was obviously a very happy one and certainly fruitful for the museums which received the collections.

A. M. V. B.

\title{
A PLACE OF ENCHANTMEN'T
}

Flinders Chase. By Mervinia Masterman. Georgian House Pty., Ltd., Melbourne. 7s. $6 d$.

Most of us have at some time known a particular spot which has been a place of enchantment. It may have been a childhood haunt, a small thicket, which appeared no less than a forest, or a lovely area of country grown familiar in many holiday visits. In this light, Mrs. Masterman shows us Flinders Chase where she and her family spent many summer months camping in a caravan.

Flinders Chase, on Kangaroo Island, South Australia, is a sanctuary of 212 square miles established in 1919 for the protection of fauna and flora. It is under the management of the Fauna and Flora Board of South Australia and has a resident ranger. An important part is the Government Apiary, from which queen bees are sent all over Australia.

The author describes the animals, including the birds living around the camp by the Rocky River. She gives many details of habits and behaviour not ordinarily found in natural history books, and one feels at home with the friendly wallabies and kangaroos which became such familiar visitors to the camp.

The text is decorated with sketches of wild creatures drawn by the author, who also painted the attractive coloured plates 
of flowers. The Chase is rich in lovely flowers, including many species of orchids for which the island is famous. A chapter on the flowers and trees gives a brief idea of the joys in store for the botanist. Short chapters on the rivers and other features and a sketch map complete a picture of the sanctuary.

A. M. V. B.

\section{THE SOCIETY'S BUSINESS}

The Council.-We are sorry to announce the retirement of Mr. Oswald Lewis, owing to pressure of other work. Mr. Lewis joined the Council in 1937.

The quarterly mecting of the Council was held on 19th April, 1951. A summary of the points of interest to members generally is given below:-

The thanks of the Council was expressed to Mr. TuteinNolthenius for giving permission to the Society to duplicate his film on Wild Life in Ceylon.

It was noted that there were indications that legislation would shortly be brought before Parliament to restrict the shooting season of ducks and geese.

It was agreed that the Propaganda and Investigation Fund should be absorbed into the General Purposes Account, leaving two funds only - the General Purposes Account and the Life Membership Fund.

The Auditors' Report, Balance Sheet, and Income and Expenditure Account were approved and adopted. (See following pages.-ED.)

General Meeting.-A General Meeting was held on 17th May. Dr. F. C. Eloff, Lecturer in Zoology at the University of Pretoria, gave a talk on Wild Life Preservation in South Africa, accompanied by a film.

Miss Robin Tomkinson's seven animal sketches, exhibited at a previous meeting, were sold by auction for the benefit of the Society. $£ 117 s$. was realized.

The Society is most grateful to Dr. Eloff for his interesting lecture and to Miss Tomkinson for her generous gift.

Gift by Dr. Van Name.-Again it is our duty and pleasure to express our gratitude to our very generous Vice-President, Dr. Willard G. Van Name, from whom a cheque for $\$ 800$ has been received. 